\title{
Effects of Isotonic Drinks Towards Students' Aerobic Endurance
}

\author{
R Sepriani ${ }^{* *}$ Sepriadi $^{1}$ \\ ${ }^{1}$ Faculty of Sport Science, Universitas Negeri Padang, Indonesia \\ *Corresponding author. Email: rikasepriani@ymail.com
}

\begin{abstract}
The purpose of this research is to prove the benefits of isotonic drinks promised by the manufacturers. This is a quasi-experimental research design involving 20 non-athlete male students. The data were analyzed using ttest.From the data analysis, it was found that there was a significant difference between aerobic endurance before and after drinking isotonic drinks, tobserve (5.398604) $>$ ttable (1.729) at level significant $\alpha=0.05$. Based on the result of the research, it can be concluded that isotonic drinks has a significant effect towards students' aerobic endurance.
\end{abstract}

Keywords: Isotonic drinks, aerobic endurance

\section{INTRODUCTION}

Endurance is one of the most essential bio motor components in physical activity. It is also one of the most important components of physical fitness. It is defined as a survival period of someone in performing a work intensity or being away from fatigue (Bafirman, 2008). Excessive fatigue causes a person's inability in doing his/her job. However, in general, it can be said that someone is considered to have a good endurance when he/she is still able to work continuously in a relatively long period of time.

An aerobic endurance describes the ability of big muscles in conducting activities with moderate intensity continuously in a long time. The decreased of aerobic endurance is caused by a decrease in hemoglobin level due to the reduced of oxygen binding. Fatigue is due to the decreased of aerobic endurance (Madina, 2007). Physical activity leads to an increase in metabolic rate and heat production resulting in loss of water and electrolytes and depletion of glycogen in the liver and muscles (Maughan \& Shirreffs, 2003). The loss of these elements can lead to dehydration which affects someone's physical performance and damages his/her health.

According to Irawan (2007), the increase of energy and heat which are generated through the process of metabolism and muscle contraction during exercising will result in the well-performed body fluids as a heat regulator. If the fluid reducing process in the body during exercising is left in a long time and is not wellbalanced with adequate fluids consumption, then the body will be dehydrated.
Drinking mineral water during exercising is not an ideal solution to optimize the body's rehydration process. According to a research done by Matsui (2002), the missing potassium and sodium from sweating is high compared to other electrolytes. He recommends that consuming supplements is important for moderate exercises. The addition of minerals such as calcium, magnesium, iron, phosphorus, zinc, and cuprum on the diet is not necessary.

Isotonic drinks are drinks which help to replace the missing fluids and electrolytes from sweating. They quickly seep into the body due to their good osmolarities and the fact that they consist of electrolytes to help replacing the body fluids. Isotonic drinks have an electrolyte composition (positive and negative ions) that are similar to the body fluids. Isotonic drinks contain water and electrolytes with the composition of sugar, citric acid, sodium citrate, sodium chloride, potassium chloride, potassium lactate, magnesium, carbonate and citrus flavor. The drinks are called as isotonic because the balance of the solution concentration corresponds to the blood fluid concentration (Susanto, 2008).

By claiming to be better than mineral water, nowadays, various types of bottled drinking water invade the market in the forms of isotonic, energy, oxygenated or hexagonal drinks. Therefore, a research on sport drinking products is needed to find out the advantages promised by the producers. It becomes important since people are very easily affected by the products' persuasive advertisements. The drinks are not only consumed by the common people but also the sport science students. 


\section{METHOD}

This quasi experimental research aims at explaining some changes due to the treatment given. This research was done on September 2017 at the football field of Faculty of Sport Science of Universitas Negeri Padang.

Population is all the subjects of the research (Arikunto, 2002). The population of this research was the students of Faculty of Sport Science of Universitas Negeri Padang. Sample is simply defined as the population which functions as the source of data in a research (Arikunto, 2010). The samples of this research were selected by using the purposive sampling technique in order to fulfill certain criteria which are male, willing to be a respondent, having a fit body, and a normal body index with the total of twenty students.

The materials used in this research were isotonic drinks. Meanwhile, the tools used were a flat and unslippery track (20 meters), a meter, a cassette, a tape recorder/radio tape player, a test format, and stakes for measuring the distance of the starting and finishing lines.

The procedure of the research are as follow: (1) Before the treatment was done, samples were selected according to their sex, age, weight, and height in order to become homogenous; (2) Then, a pretest was done by doing the bleep test to measure the $\mathrm{VO}_{2 \max }$; (3) The samples were given a break time. While having the break, they were forbidden from consuming any foods/drinks and vitamin supplements; (4) The $\mathrm{VO}_{2 \max }$ was re-measured by giving them the isotonic drinks thirty minutes before the test; and (5) Data were analyzed by using the t-test.

\section{RESULT}

Based on preliminary research data (pre-test), it is found that the lowest oxygen volume was 27.2 while the highest was 47.1. From the data analysis, it is found that the maximum oxygen volume value $\left(\mathrm{VO}_{2 \max }\right)$ was 34.62 , the standard deviation was 5.86, and the median was 34. The frequency distribution is shown in the following table 1 :
Table 1. The Frequency Distribution of Maximum Oxygen. Volume $\left(\mathrm{VO}_{2 \mathrm{Max}}\right)$ of Isotonic Drinks in Pretest.

\begin{tabular}{cccc}
\hline $\begin{array}{l}\text { Class } \\
\text { Interval }\end{array}$ & $\begin{array}{c}\text { Absolute } \\
\text { Frequency }\end{array}$ & $\begin{array}{c}\text { Relative } \\
\text { Frequency }(\%)\end{array}$ & $\begin{array}{c}\text { 'lassificati } \\
\text { on }\end{array}$ \\
\hline$<33,0$ & 10 & 50 & Very Poor \\
$33,0-36,4$ & 3 & 15 & Poor \\
$36,5-42,4$ & 4 & 20 & Fair \\
$42,5-46,4$ & 2 & 10 & Good \\
$46,5-52,4$ & 1 & 5 & Tery Good \\
$>52,4$ & 0 & 0 & Excellent \\
Total & 20 & 100 & \\
\hline
\end{tabular}

From the table, it is analyzed that from the 20 samples, the maximum volume of oxygen $\left(\mathrm{VO}_{2 \mathrm{max}}\right)$ was in the class interval of $<33.0$ for about 10 students $(50 \%)$ who were in "very poor" classification. Meanwhile, in class interval of 36.5-42.4, there were 4 students $(20 \%)$ who were in the "fair" classification. In the class interval of $33.0-36.4$, there were 3 students $(15 \%)$ who were in the "poor" classification. In addition, in the class interval of 42.5-46.4, there were 2 students $(10 \%)$ who were in the "good" classification and in the class interval of 46.5-52.4, there was 1 student $(5 \%)$ who was in the "very good" classification. However, no one was in the class interval of $>52.4$ which was in the "excellent" classification. Details can be seen in the following histogram:

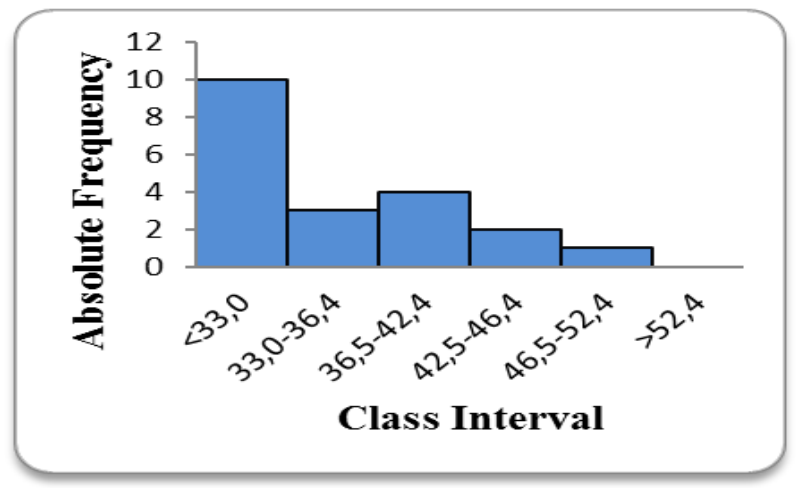

Picture 1. Maximum Oxygen Volume ( $\left.\mathrm{VO}_{2 m a x}\right)$. Histogram of the Isotonic Drinks in Pretest

After the students were given the isotonic drinks, the lowest average score of the maximum oxygen volume $\left(\mathrm{VO}_{2 \max }\right)$ was 30.6 while the highest was 48.4. From the data analysis, it is found that the maximum oxygen volume $\left(\mathrm{VO}_{2 \max }\right)$ score was 38.19 , the standard deviation was 5.19 , and the median was 38 . The frequency distribution is shown in the following table 2: 
Table 2. The Frequency Distribution of Maximum Oxygen Volume $\left(\mathrm{VO}_{2 \max }\right)$ of Isotonic Drinks in Posttest

\begin{tabular}{|c|c|c|c|}
\hline Class & Absolute & Relative & Classific \\
\hline Interval & Frequency & Frequency $(\%)$ & ation \\
\hline$<33,0$ & 4 & 20 & $\begin{array}{l}\text { Very } \\
\text { Poor }\end{array}$ \\
\hline $\begin{array}{c}33,0- \\
36,4\end{array}$ & 4 & 20 & Poor \\
\hline $\begin{array}{l}36,5- \\
42,4\end{array}$ & 7 & 35 & Fair \\
\hline $\begin{array}{c}42,5- \\
46,4\end{array}$ & 4 & 20 & Good \\
\hline $\begin{array}{c}46,5- \\
52,4\end{array}$ & 1 & 5 & $\begin{array}{l}\text { Very } \\
\text { Good }\end{array}$ \\
\hline$>52,4$ & 0 & 0 & $\begin{array}{c}\text { Excellen } \\
\mathrm{t}\end{array}$ \\
\hline Total & 20 & 100 & \\
\hline
\end{tabular}

From the table, it is found that from 20 students, the score of the maximum oxygen volume $\left(\mathrm{VO}_{2 \max }\right)$ was mostly found in the class interval of <36.5-42.4 for about 7 students (35\%) who were in the "fair" classification. Meanwhile, in the class interval of $<33.0$, there were 4 students $(20 \%)$ who were in the "very poor" classification. In the class interval of 33.0-36.4, there were 4 students $(20 \%)$ who were in the "poor" classification. In addition, in the class interval of 42.546.4 , there were 4 students $(20 \%)$ who were in the "good" classification and in the class interval of 46.552.4 , there was 1 student $(5 \%)$ who was in the "very good" classification. However, no one was in the class interval of >52.4 which was in the "excellent" classification. Details can be seen in the following histogram:

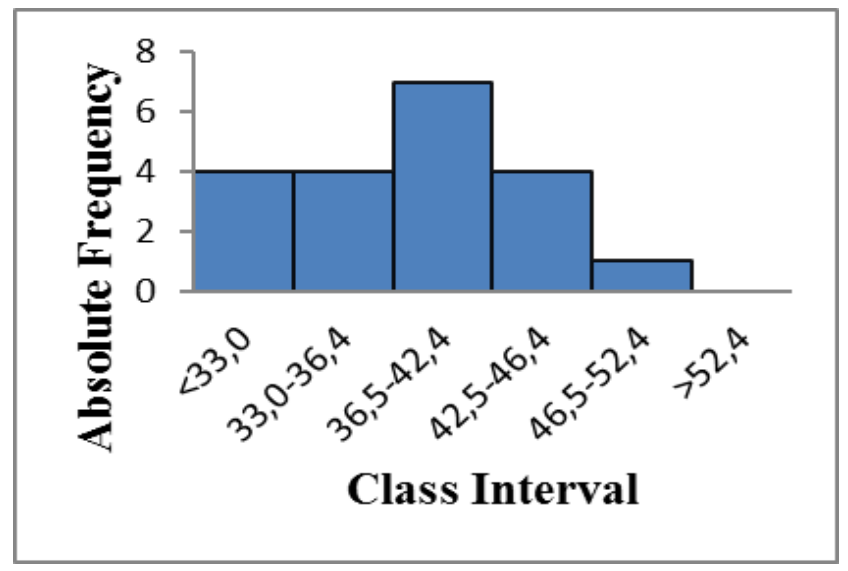

Picture 2. Maximum Oxygen Volume ( $\left.\mathrm{VO}_{2 \max }\right)$

Histogram of the Isotonic Drinks in Posttest

The Average Score of the Maximum Oxygen Volume in Pretest and Posttest

In this research, the measurement of the $\mathrm{VO}_{2 \max }$ was conducted before and after the isotonic drinks were given by using a bleep test. The score of the $\mathrm{VO}_{2 \max }$ before the isotonic drinks were given was 34.62 . Thirty minutes after the isotonic drinks were given, a bleep test was conducted and the Maximum Oxigen Volume was measured. The score was 38.19. Details can be seen in the table 3 .

Table 3. The average score of the $\mathrm{VO}_{2 \max }$

\begin{tabular}{cc}
\hline \multicolumn{2}{c}{ The Average Score of VO2 Max } \\
\hline Pretest & Posttest \\
34,62 & 38,19 \\
\hline
\end{tabular}

For more details, the average score of the maximum oxygen volume $\left(\mathrm{VO}_{2 \mathrm{max}}\right)$ before and after the treatment can be seen in the histogram below:

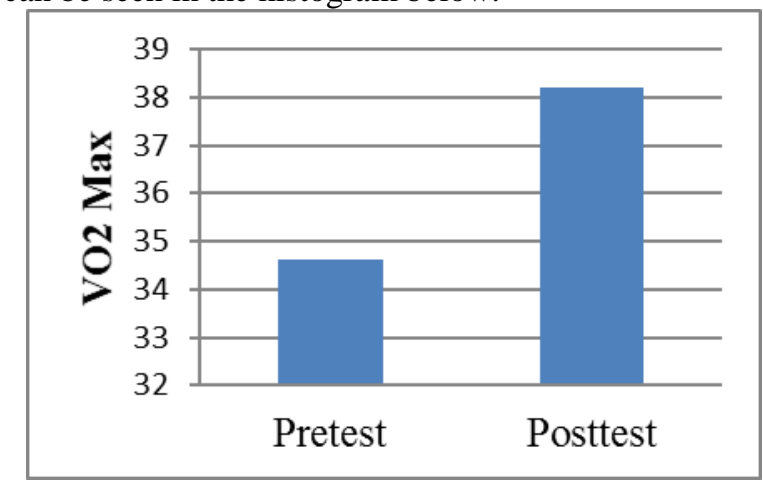

Picture 3. The Histogram of the Average Score of $\mathrm{VO}_{2 \max }$

The cardiorespiratory endurance or aerobic capacity is the most important component of physical fitness. A person with a good aerobic capacity has an efficient heart, effective lungs, and good blood circulation which supply the muscles so that he/she is able to work continuously without having excessive fatigue. A pulmonary cardiac endurance can be measured by using the achieved $\mathrm{VO}_{2 \max }$ level. If the maximum $\mathrm{VO}_{2 \max }$ level is achieved within the target, the physical fitness is required (Guyton, 2006).

In performing physical activities, there is an increase in oxygen consumption which will reach the maximum number during the work loading process. This relates to the $\mathrm{VO}_{2 \max }$ (Guyton, 2006). The $\mathrm{VO}_{2 \max }$ indicates the ability of the cardiorespiratory system to take, carry and use the oxygen for the work performance during exercising. This measurement is usually used as one of the best indicators of cardiovascular fitness function and immune. Someone with good fitness has higher $\mathrm{VO}_{2 \max }$ score and can perform more powerful physical activity than those who are not in a good condition. The $\mathrm{VO}_{2 \max }$ is influenced by genetic and environmental factors such as lifestyles, diets and exercises (Cengiz A, 2008 \& Patton, 2001).

The isotonic drinks given have an electrolyte composition which is similar to human body fluids. The isotonic drinks in packs of $350 \mathrm{cc}$ are consumed 30 
minutes before the test. They have the electrolyte concentration of $21 \mathrm{mEq} / \mathrm{L}$ sodium, $5 \mathrm{mEq} / \mathrm{L}$ potassium, $1 \mathrm{mEq} / \mathrm{L}$ calcium, $0.5 \mathrm{mEq} / \mathrm{L}$ magnesium, $16 \mathrm{mEq} / \mathrm{L}$ chloride, $10 \mathrm{mEq}$ citrate and $1 \mathrm{mEq}$ lactate.

The measurement of the $\mathrm{VO}_{2 \max }$ as one of the aerobic endurance parameters is done toward the samples before and after the isotonic drinks were given using a bleep test. The score of the $\mathrm{VO}_{2 \max }$ before the isotonic drinks given was 34.62. Later, the samples were rested for 10 days and re-measured by giving the drinks thirty minutes before the test. The later score was 38.19 .

From the data analysis, it is found that there is a significant difference of $\mathrm{VO}_{2 \max }$ before and after the Isotonic drinks were given with t-count $(5,398604)<\mathrm{t}-$ table $(1,729)$ with the level of significant $\alpha=0,05$. This research is in line with the one done by Azizah (2015) who states there is a significant difference in $\mathrm{VO}_{2 \max }$ before and after the isotonic drinks were given. The results of this research indicate that isotonic drinks have an effect on the increase of the $\mathrm{VO}_{2 \max }$ since their composition is similar to human body fluids. Thus, they are easily absorbed by the human body. From the ingredients, it is observed that the isotonic drinks contain minerals that are needed by the body to perform activities.

When physical activities are performed like working and exercising, the energy, water and mineral consumption process also happen. The water is reduced through urine and sweat. Meanwhile, some minerals are casted away through sweat. Normally, (with an adequate dietary intake), the energy required during the performance of activities is supplied from the oxidation of fats, carbohydrates and a small contribution from the protein breakdown for approximately $5 \%$. The heavier the intensity of the physical activity is, the greater the energy is required and the greater the carbohydrate is used as the source of energy (Koswara, 2006).

The released of body fluids through sweat influences the release of minerals of the body which are soluble in the water. This is in line with Wiarto's opinion (2013) who states sweating out will carry a number of macro electrolytes such as sodium, potassium and chloride. Another expert, Darmawan (2013), suggests that the greater the intensity of exercise, temperature and humidity is, the greater the loss of water will be. The discharge of water and minerals such as sodium, chlorine, potassium, calcium, and magnesium which maintain the fluid balance in the body, the heart rhythm, and the muscle relaxation will result in exhaustness. The lack of minerals due to this process can be replaced by the isotonic drinks which contain minerals that the body needs to prevent fatigue and speed recovery.

\section{CONCLUSION}

The average score of VO2 max in pretest was 34.62; The average score of $\mathrm{VO} 2$ max in posttest was 38.19 ; and there are statistical differences of the students' aerobic endurance in pretest and posttest.

\section{REFERENCES}

[1] Anwari, Irawan M. 2007. Metabolisme Energi Tubuh dan Olah Raga. I Jurnal, Vol. 1 No.7

[2] Arikunto, Suharsimi. 2010. Prosedur Penelitian. Jakarta: Rineka Cipta.

[3] Bafirman. 2008. Buku Ajar Kondisi Fisik. Padang: FIK UNP.

[4] Cengiz A, Robert AR, Ian K. 2008. Prediction of VO2 max from an Individualized Submaximal Cycle Ergometer Protocol. JEP online 11: 3.

[5] Darmawan, Aji Budi. 2013. Diet Sehat Air Kelapa. Yogyakarta: Media Pressindo.

[6] Guyton, A.C., Hall J.E. 2006. Buku Ajar Fisiologi Kedokteran, Edisi ke-11. Jakarta: EGC.

[7] Inoue, Y., T. Osawa, A. Matsui, Y. Asoi, Y, Murokami T. Matsui, and H. Yano. 2002. Changes of Serum Mineral Concentration in horsis during exercise. Asian aust.J. Anim.Sci. 5 (4): 531-536.

[8] Koswara, Sutrisno. 2006. Minuman Isotonik. Semarang: Universitas Muhammadiyah Semarang.

[9] Madina, D, 2007, Nilai Kapasitas Paru dan Hubungannya dengan Karakteristik Fisik pada Atlet Berbagai Cabang Olah Raga.

[10] Patton H. 2001. Textbook of Physiology. Philadelpia: WB Saunders Company.

[11] Shirrefs, S.M. 2003. Markers of Hydration Status. European Journal of Clinical Nutrition. 57: Suppl 256-59 